\title{
The Body Politic from Medieval Lombardy to the Dutch Republic: An Introduction
}

\author{
Vasileios Syros \\ University of Jyväskylä, Finland \\ vasileios.syros@jyu.fi
}

The content of this special issue is based on three of the presentations delivered at the international conference "The Body Politic and Social Harmony: From the Middle Ages to the Present." The event was held on 28 and 29 May 2018 at the Meeting and Conference Center Soeterbeeck in Ravenstein, The Netherlands, under the auspices of the Royal Netherlands Academy of Arts and Sciences (KNAW), and corresponded with my appointment as KNAW Visiting Professor at the Faculty of Philosophy, Theology and Religious Studies at Radboud University Nijmegen during spring 2017 and spring 2018.

The body politic metaphor, widely invoked in envisioning various modes of the existence and operation of a harmonious society, has been an enduring feature in the evolution of political thought, both in the "West" and elsewhere. The conference drew upon the cumulative expertise of scholars from different disciplinary backgrounds. It explored iterations of the body politic metaphor and its normative value for conceptions of social and political harmony from the Middle Ages to the present in the European, Islamic, Jewish, Indian, Russian, and East Asian traditions of political theorizing. The aim of the event was to explain why the corporeal model exerted such a strong and lasting impact. It also gave the attendees the opportunity to contribute to discussions about avenues for future collaborative work.

Despite the predominance of the vision of the state as an artifact or a machine, vestiges of the notion of the state as a microcosm or replica of a natural body have resurfaced in light of recent debates about biopolitics. Western societies are confronted with the need to tackle problems that have arisen alongside ethnic and religious diversity. The designation "sick man of Europe" has been vested with a variety of connotations and employed to describe the political or economic ills affecting various European countries, ranging from Greece and Italy to Germany, Finland, and the United Kingdom. Corporeal metaphors persist and will most likely continue to do so as long as corporeality 
and the way humans relate to their own bodies affect the way they look at human society, nature, and the world. The emphasis on the etiological aspects of the entire debate on corporeal analogies foregrounds the differences between a mechanistic notion of the state and the belief that there is a continuum between political life and the natural world.

Statements like Hamlet's "Something is rotten in the state of Denmark"; debates about the Ottoman Empire as the "sick man on the Bosphorus"; and remarks that for China it is "unhealthy" to choose a lifelong president - all of these speak to a tendency to deliberately or unintentionally look at politics through the lens of medical diagnostics. Moreover, there is a cluster of ideas of medical provenance that are related to the rise and fall of nations in terms of lifecycles, where vigor is followed by weakness, sickness, and death. This accounts for the still popular idea that each century has its lead nation; from Voltaire's Le Siècle de Louis XIV to the "American Century" and the notion, quite alive in the headquarters and smoke-filled rooms of the European Union, that the "Old Continent" has to rejuvenate and reinvent itself so as to make sure that it avoids becoming completely marginal and obsolete in the "Chinese Century." But, at the same time, the corporeal idea points to a range of phenomena that defy the human endeavor to determine the operation of a political entity, pretty much in the same way as natural occurrences often challenge the validity and accuracy of scientific knowledge about the natural world.

Andrea Gamberini's article "The Body Politic: Metaphors in Communal and Post-Communal Italy - Some Remarks on the Case of Lombardy" traces the fortunes of the corporeal metaphor in the political history of Lombardy in the communal and post-communal periods (twelfth-fifteenth centuries). Gamberini aptly demonstrates that the body politic motif lent itself to various uses that, in turn, generated diverse ideas about the association of the political community with a living organism. The special value of Gamberini's analysis lies in its uncovering the different layers of the political culture and a variety of modes of legitimizing claims to political authority as well as elucidating the performative aspects of the corporeal idea. Intriguingly, Gamberini opts to focus on what he designates "pragmatic" texts, including letters, legal documents, and chronicles, rather than the works of seminal medieval writers and systematic treatises of political theory.

The correspondences between the body politic and the physical body were first articulated in the context of the relationship between city and country. Almost universally in the northern regions of Italy until the tenth century, the countryside was closely dependent, in administrative and jurisdictional terms, on urban centers. This phenomenon reflected the residual influences of the Roman paradigm of political organization, which revolved around cities as the 
main loci of political authority. Consequently, the cities and the countryside formed a unity. This unity, however, was disrupted in the post-Carolingian era, as the decline of the imperial order led to the dissolution of the large public units. These developments necessitated the diffusion of political authority and the emergence of new political actors, i.e., the bishops in the cities, and the manors and lords in the surrounding countryside. More importantly, common citizens aspired to greater involvement in civic affairs and control over the countryside, and they challenged episcopal authority. The rearrangement of the relations between cities and rural areas was guided by economic concerns, the creation of conditions conducive to trade, and control over the channels of supply.

During this process of expansion into the countryside, the communes employed "soft" power through, e.g., new agreements, the purchase of land, and the creation of villages, as well as military operations. They also exploited the power vacuum caused by the fall of the Carolingian model of counties and evolved into the indisputable power center of the comitatus. They sought to vindicate their power and their control over the countryside, by evoking as an analogy the relationship between the mother and her children, or by associating the urban centers and the countryside with the head and the various organs of the body, respectively. This constellation of metaphors prevailed until the early fifteenth century and was used as a potent rhetorical tool by influential public officials who possessed skills but needed to enhance their social status in order to obtain senior posts in the Chancellery and other major decision-making organs.

Alessandro Mulieri ("The Political Thinker as a Civil Physician: Some Thoughts on Marsilius of Padua and Machiavelli beyond Leo Strauss' al-Fârâbî") discusses the use of corporeal metaphors in two of the most fascinating and controversial figures of medieval and early modern political thought, Marsilius of Padua (1270/90-1343) and Niccolò Machiavelli (1469-1527). Earlier scholarship has pointed to strong affinities between the two authors, and Marsilius has often been portrayed as prefiguring Machiavelli. Mulieri takes up a longstanding scholarly debate on potential links between Plato's philosophy and political discourse in medieval and early modern Italy. The assumption about the indirect or residual influences of the Platonic notion of the philosopherking, as mediated through Islamic and Jewish sources, was set forth by the famous historian of political thought Leo Strauss (1899-1973). Strauss depicted the ninth-century author al-Fârâbî as inaugurating a philosophical project that advocated the alliance of philosophers and rulers and found one of its most enthusiastic proponents in Marsilius. 
Mulieri offers a fresh reading of the relevant sources and presents powerful arguments against interpreting Marsilius and Machiavelli as following the Platonic tradition. On the contrary, as Mulieri shows, their deployment of medical motifs encapsulates a set of ideas about effective political action that are incompatible with two of the central tenets of Plato's philosophy, namely that (a) philosophy constitutes absolute self-knowledge, one of the key conditions for salutary rule; and (b) that the ideal legislator or lawgiver needs to be a philosopher. One of the strains of medieval thought upheld the autonomy of the sphere of philosophy and was associated with the fourteenth-century Latin Averroist John of Jandun, who was closely associated with Marsilius. For Jandun, one the principal functions of the philosopher is to educate and guide the masses and, at the same time, serve as the purveyor of wisdom to those in power. Marsilius, on the other hand, highlighted the collective and cumulative character of wisdom. In doing so, he negated the elitist dimensions inherent in Jandun's theory about the correlation between human perfection and the quest for philosophical perfection. His engagement with the Averroist tradition is informed by his concern to refute the doctrine of the pope's plenitude of power. Marsilius challenged the notion that individuals who are devoted to noble activities should be assigned supremacy and authority over those who are engaged in less noble endeavors. He rehabilitates the role of the common people, especially when acting as a whole, in unison. He depicts them as one the main agencies in the process of lawmaking and the government of the political community. Mulieri emphasizes the link between Marsilius' medical training and his effort to reconfigure the Averroist theory of philosophical perfection. He demonstrates how Marsilius transformed the philosopher qua metaphysician into a civil physician at the service of the political community.

These themes underpin Machiavelli's political theory as well. But while Marsilius is committed to the value of contemplation as the source of human perfection and felicity, Machiavelli, in his major works, Il Principe (The Prince) and Discorsi sopra la prima deca di Tito Livio (Discourses on the First Decade of Titus Livy), turns the tables on earlier thinkers, who attributed the highest priority to philosophy and contemplation, and celebrates instead the founders of states and religions. One of the novelties of Mulieri's contribution is in his appraisal of the ideas of the Florentine author concerning the role of the philosophers. Mulieri argues that in one of his minor writings Machiavelli gives philosophers like Plato and Aristotle, who imagined and "founded" republics in their texts, a status similar to that of the founders or reformers of actual republics. Machiavelli visualizes the art of government and the various ways of addressing anomalies in political life as analogous to medicine. Like Marsilius, he underscores the correspondences between the body politic and the body 
natural. Machiavelli's thinking intersects with that of his Paduan predecessor in the use of a medical lexicon. Both thinkers apply a method of investigation of political phenomena that is akin to the process of tracing the composition and growth of natural organisms and identifying the most efficient remedies for the ills of the political organism. Yet, while Marsilius is keen to show the deleterious effects of civil discord and friction, Machiavelli does not regard harmony as an element essential to the functioning of the state, illustrating instead the potential benefits of social disharmony as one of the factors at work in the creation of laws conducive to public utility and freedom. Machiavelli contends, for instance, that one of the strengths of ancient Rome was the perpetual confrontation between the patricians and the plebeians.

As is the case with Marsilius, for Machiavelli the process of promulgating laws is closely related the people and to the cumulative experience of specific individuals, who possess the necessary skills to act as legislators. In keeping with his thesis that different conditions call for different modes of political action, Machiavelli considers laws to resemble medical experiments. As such, the lawgiver, in his capacity as a physician, needs to rely on the body of knowledge generated by prior and contemporary physicians and must enlist popular support in order to ensure the implementation of the laws.

While Marsilius operates within the framework of Aristotelian biology, Machiavelli's theory reflects the influence of Galen's humoral model. Another significant difference between Marsilius and Machiavelli concerns the degree of certainty each thinker attributes to political inquiry. The Defensor pacis' prime objective is to outline a scheme of political organization that can be universally applicable. Marsilius' political program is animated by the belief in the possibility of harnessing sound knowledge about the factors leading to the genesis, evolution, and destruction of a political entity. Machiavelli's thought, on the other hand, is colored by a sense of relativism surrounding generic prescriptions and rules about successful political agency.

The "democratic" commitment that lies behind the usage of the body politic metaphors in Marsilius and Machiavelli is more sharply delineated in the Tractatus Politicus (Political Treatise) of Baruch Spinoza (1632-1677). In his essay “From the King's Two Bodies to the People's Two Bodies: Spinoza on the Body Politic," Marin Terpstra offers original and detailed insights into Spinoza's deployment of the corporeal imagery and identifies three key aspects: (1) the association of the political community with the human organism; (2) the function of a single individual as the representative of the entire community; and (3) the unity and cohesion of society. Spinoza envisions the political body as a mixed, composite body that operates in conformity with the laws governing the birth, growth, and death of natural entities. However, he departs from the 
medieval usage of the body politic, which revolves around the notion of the king as an agent having both a physical existence and a political body. Spinoza challenges the Christian notion of a mystical body; he analogizes a state that possesses intellectual and physical capacities to a human being that is endowed with similar abilities. An orderly society, according to Spinoza, is a society that functions "as if" guided by one spirit and contingent upon the unity of its individual members.

Terpstra carefully examines several aspects of Spinoza's thinking about the body politic and teases out the implications of Spinoza's deviation from the medieval model of the king's political body. One of the main goals of Spinoza's philosophical project is to propose institutional safeguards against the abuse of power and the emergence of a single individual as a tyrant. Thus, he recommends a large, multi-member council that can be immune to and resist the temptations and pathologies associated with political power. Spinoza does not rule out the possibility that a king can be solicitous of the wellbeing and security of his subjects. He insists, however, that the king's function should align with the priorities and preferences of the largest portion of the citizenry. The ruler should therefore comply with the constitution of the political community, while being in charge of officeholders and magistrates who obey the sovereign not as a physical person but as the possessor of a political body. In ways reminiscent of Marsilius' political theory, Spinoza draws on the idea of collective wisdom: he underscores the intrinsic incapacity of any person, however sagacious that person may be, to have a complete understanding of all things. Accordingly, he advocates the creation of an advisory body made up of select citizens that can offer advice to the ruler and, ultimately, ensure that the ruler's decisions and actions serve the common good and not the ruler's personal interests. In light of the analogies between political and natural bodies, Spinoza cautions against radical alterations to the nature or character of the political community. In this regard, he endorses succession as a way to avert a power vacuum and political struggles that can arise after the death of a king. While the recurrent need to elect a king can be a source of instability, succession taking place in accordance with existing laws is the best guarantee for the longevity of the political body. In Terpstra's reading, Spinoza's deconstruction of the notion of the political body illustrates the role of imagination in social life. Spinoza stresses the imaginary character of the metaphor and draws political conclusions from that insight, but is also alert to the pernicious influence of imagination, when, for instance, people come to embrace the belief that a monarch is in a position to adequately represent the entire state.

The very idea that the ruler is akin to a physician who ministers to the needs of the body politic derives from the recognition that the political organism is 
an entity with its own rules and modes of operation. The vision of the ruler or statesman as the equivalent of the physician catering to the needs of the patient can be construed as a justification of an absolutist conception of government. It rests on the assumption that the sovereign has, by virtue of his knowledge and skills, the authority and power to determine the modes of ensuring the wellbeing of society and to claim obedience to his commands. A more republican/democratic variant of this model would posit the people's right to place under scrutiny and endorse or resist the policies and laws promulgated by the government, just as a patient is entitled to choose and retain or dismiss a physician, if the latter proves to be ineffectual. ${ }^{1}$

A common thread uniting the sources analyzed in this special issue is that they reconstruct a line of thinking that calls for the diffusion of political power and favors a republican scheme of political organization. A broader issue emerging from the articles collected here regards the nature and limitations of technical knowledge about the exercise of political power. The association of medicine and the art of rulership foregrounds the need for the ruler to possess know-how about the various aspects of government. Current politics is characterized by the growing dominance of technocracy often at the expense of democratic principles.

This special issue was completed amidst one of the most devastating pandemics in recent history, the spread of the coronavirus (CoviD-19). Lombardy has become the epicenter of the coronavirus outbreak in Italy; the Italian authorities, in a last-ditch effort to contain the disease, have placed the entire country in indefinite lockdown. Many governments around the world have followed suit and responded with drastic measures, mass quarantines, curfews, border closures, and the isolation of cities or entire regions. UK Prime Minister Boris Johnson tested positive for coronavirus just a few minutes before this introduction was finalized. It remains to be seen to what extent leaders are willing to acknowledge their limitations and heed the advice and prescriptions of real physicians and medical experts.

1 I am grateful to Filimon Peonidis for sharing his thoughts on this point. 